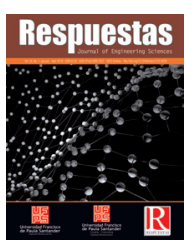

Original Article
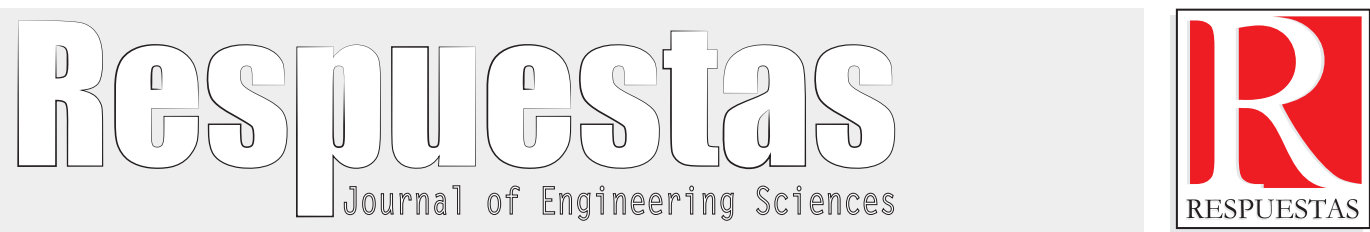

\title{
Evaluation of damage to the lumbar spine vertebrae L5 by finite element analysis
}

\author{
Evaluación del daño en la vértebra lumbar L5 mediante análisis por elementos finitos \\ Sergio Andrés Ardila-Parra ${ }^{1}$, Heller Guillermo Sánchez-Acevedo², Octavio Andrés González-Estrada ${ }^{3 *}$ \\ ${ }^{1}$ MSc Ingeniería Mecánica, sergio.ardila9@correo.uis.edu.co, ORCID: 0000-0002-9661-5450, Universidad Industrial de Santander, Bucaramanga, Colombia. \\ ${ }_{2}^{2}$ hD Ingeniería Mecánica, hgsanche@uis.edu.co, ORCID: 0000-0003-0081-2212, Universidad Industrial de Santander, Bucaramanga, Colombia. \\ 3*PhD Ingeniería Mecánica, agonzale@saber.uis.edu.co, ORCID: 0000-0002-2778-3389, Universidad Industrial de Santander, Bucaramanga, Colombia.
}

How to cite: S. Ardila-Parra, H. Sánchez-Acevedo y O. González-Estrada, "Evaluation of damage to the lumbar spine vertebrae L5 by finite element analysis". Respuestas, vol. 24, no. 1, pp. 48-53, 2019.

Received on May 05, 2018; Approved on September 15, 2018

\section{ABSTRACT}

\section{Keywords:}

Bone damage

FEA based on

image

Metastasis

Bone segmentation

Vertebrae
Bone metastasis to the spine, pelvis or hip in patients with prostate cancer is a pathology that occurs in approximately $80 \%$ of cases. Metastases in the spine can cause pain, instability and neurological injuries. Therefore, it is relevant to evaluate when critical conditions have been reached and the structural integrity of the bone is compromised. Numerical methods based on patient data, obtained through post-processing of medical images, provide a tool to model the complexity of the biological tissue material. Computed axial tomography (CT) together with segmentation tools allows the reconstruction of 3D bone models that include mechanical properties, and that represents the anisotropic condition of bone structures. In this work, we present the L5 lumbar vertebra model of a patient affected by metastases and evaluate biomarkers to indicate the level of damage, compared with the reference case of healthy bone in an initial stage.

\section{RESUMEN}

Palabras clave:

Daño óseo

La metástasis ósea a la columna vertebral, pelvis o cadera en pacientes con cáncer de próstata es una

FEA basado en la imagen

Metástasis

Segmentación ósea

Vértebras patología que se presenta en aproximadamente el 80\% de los casos. Las metástasis en la columna vertebral pueden causar dolor, inestabilidad y lesiones neurológicas. Por lo tanto, es importante evaluar cuándo se han alcanzado las condiciones críticas y se ha comprometido la integridad estructural del hueso. Los métodos numéricos basados en los datos de los pacientes, obtenidos mediante el post-procesamiento de imágenes médicas, proporcionan una herramienta para modelar la complejidad del material tisular biológico. La tomografía axial computarizada (TC) junto con herramientas de segmentación permite la reconstrucción de modelos óseos en 3D que incluyen propiedades mecánicas, y que representan el estado anisotrópico de las estructuras óseas. En este trabajo se presenta el modelo de vértebras lumbares L5 de un paciente afectado por metástasis y se evalúan los biomarcadores para indicar el nivel de daño, en comparación con el caso de referencia de hueso sano en una fase inicial.

\section{Introduction}

Primary tumors are diagnosed increasingly soon, making the detection of metastases more important and more difficult [1], [2]. Patients with advanced breast and prostate cancer almost always develop bone metastases [3], these being the two most common types of cancer in men and women in
Colombia [4]. About $39 \%$ of patients with breast or prostate cancer develop vertebral metastases, but if patients with advanced status of these types of cancer are considered, the prevalence rises to values close to $70 \%[5],[6]$.

On the other hand, advances in diagnostic medical imaging techniques [7], segmentation algorithms

*Corresponding author.

E-mail address: agonzale@saber.uis.edu.co (Octavio Andrés González Estrada)

(c) $(1) \Theta$ Peer review is the responsibility of the Universidad Francisco de Paula Santander.

(c) ${ }_{\mathrm{EY}} \mathrm{ND}$ This is an article under the license CC BY-ND (http://creativecommons.org/licenses/by-nc-nd/4.0/). 
[8], [9], numerical methods for studying complex biological systems [10], [11], and capacity Growing computer equipment has marked the development of personalized medicine, once tools have been obtained to investigate the anatomical and functional complexities of patients. Diagnostic techniques such as computed tomography (CT) and magnetic resonance imaging (MRI) are important because they promote the development of personalized medicine based on the individual's profi le, and not on the disease [12], [13]. With these techniques, specifi c patient models can be developed that allow realistic numerical simulations to obtain more information regarding the patient [10], [14] - [16]. These patient-specifi c models can be used for the mechanical characterization of bone structure and to estimate damage in scenarios such as, for example, implants, osteoporosis or bone loss due to metastasis [6], reducing the risk of critical events and allowing schedule treatments or surgical interventions that seek to improve the patient's quality of life.

Three-dimensional models can provide a wealth of useful information that helps doctors determine the state of a bone or even an organ [10]. In the case of vertebra metastasis, it is possible to obtain a $3 \mathrm{D}$ model of bone structures using segmentation tools from the images of sagittal, coronal and axial sections of a CT scan, [17], [18]. Subsequently, numerical methods can be used to detect changes in the bone and assess its structural integrity [15], [16].

This paper proposes a methodology to fi nd changes in the structural integrity of vertebrae after the diagnosis of prostate cancer, using numerical models that consider the anisotropic properties of bone tissue. These models provide information to assess the risk of vertebral collapse, which would help to anticipate the use of treatments that reduce the risk of invalidating complications caused by fractures. First, we process the medical diagnostic image of the CT scan using the segmentation software Materialize Mimics $v 19^{\circ}$ to generate the 3D model of an L5 vertebra affected by metastasis. Two stages of the disease are compared, considering the fi rst as a healthy or reference vertebra. The properties of the anisotropic material associated with bone [8], [19] are defi ned from the information available in the TACs. Then, a fi nite element analysis (FEA) is performed with Ansys v18.1 $1^{\circ}$ software to study the mechanical response of the bone structure. The 3D fi nite element model allows representing irregular geometry and the lack of homogeneity of bone tissue [20]. Finally, some physiological biomarkers are proposed to assess the risk of collapse of the vertebra before osteolytic, osteoblastic or mixed lesions as metastasis progresses.

\section{Materials and methods}

The computerized axial tomography images are used to construct the 3D model, the package of collected images is based on grayscale information (Hounsfi eld units). Two 3D models of a patient's L5 vertebra are analyzed: a model with the vertebra in the state corresponding to the year 2009, with the healthy vertebra, and the other with the vertebra evaluated in 2014, when the patient had developed metastases. Segmentation is performed for CT images with $2.50 \mathrm{~mm}$ thick layers and a step between $2.00 \mathrm{~mm}$ layers. The TAC data is imported into the Mimics software, where the geometric details are defi ned and then exported to 3-Matic to generate a volumetric mesh, see Figure 1.

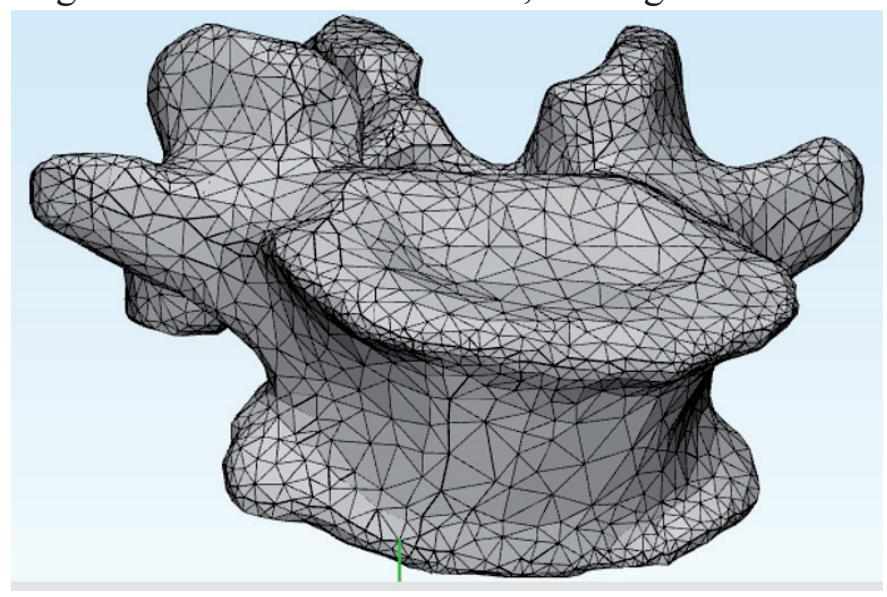

Figure 1. Volumetric mesh created to evaluate each vertebra

The volumetric mesh is imported again into Mimics to assign the anisotropic properties in each element. The relationship between Hounsfi eld (HU) values and apparent density $\rho \_a p p$, given in g/ $\mathrm{cm}^{3}$, it is assumed linear [19], by means of empirical expression: 


$$
\rho_{a p p}=1.22 \cdot H U+47
$$

For each element, an apparent Young's module, E, is assigned in MPa. Different models in the literature relate density and elasticity in patient-specific studies [19], [21]. The empirical expression that directly relates Young's module with apparent density is written as [19]:

$$
E=0.63 \cdot \rho_{a p p}{ }^{1.35}
$$

The models generated with their respective volumetric and surface elements are exported to Ansys, where the boundary conditions are incorporated. Mesh independence tests are performed and quadratic tetrahedron meshes (TET10) with 52662 degrees of freedom are chosen. Also, it is verified that the elements have a skewness metric of less than 0.9. Once the numerical models have been defined, it is possible to verify whether the elastic properties of the vertebra have changed. The most representative loads in the lumbar vertebra L5 are those that act on the intervertebral discs. For the present investigation, a vertical distributed axial load $\mathrm{Fz}=$ $-319 \mathrm{~N}$ is applied in the models, as shown in Figure 2, [22]. Additionally, the vertebra has been fixed at the bottom, modeling the interaction with the next intervertebral disc.

The own values and the norm are considered as biomarkers of the patient's pathological process $\mathrm{L}_{2}$ of the stiffness matrix of the vertebrae, as well as stress and strain values under typical loads.

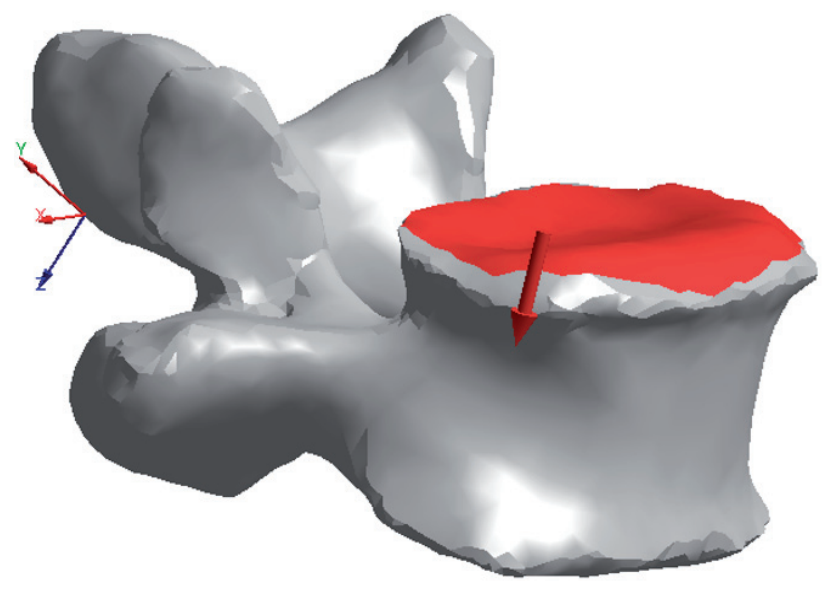

Figure 2. Loads on the vertebra

\section{Results and Discussion}

To verify the changes in the mechanical properties of the vertebra, the stiffness matrix of the domain generated in the mapping of the non-homogeneous properties was analyzed. The sparse matrix is evaluated in terms of its eigenvalues and its norm $\mathrm{L}_{2}$. The first six eigenvalues were taken to compare the two models, and the percentage difference between them was calculated. The values obtained for the vertebrae of 2009 and 2014 are reported in Table 1. The norm L 2 for TAC of 2009 was $5.08 \mathrm{E}+04$ and that of 2014 was $4.68 \mathrm{E}+04$ for a percentage difference of $7.92 \%$. These values are higher than the estimated bone loss of $2 \%$ for the 5 -year period because the relationship between density and biomarkers is not linear. Likewise, the uncertainty associated with the management of diagnostic images must be taken into account. However, differences of up to $13.43 \%$ can be observed, in the case of the second eigenvalue [17] in Table 1.

Table I. Eigenvalues for the stiffness matrices taken from the TACs of 2009 and 2014

\begin{tabular}{|c|c|c|}
\hline $\mathbf{2 0 0 9 .}$ & $\mathbf{2 0 1 4 .}$ & Difference \%. \\
\hline 50810,21 & 46783,04 & $-8,61$ \\
\hline 48967,56 & 43168,24 & $-13,43$ \\
\hline 44181,39 & 41838,73 & $-5,60$ \\
\hline 42713,13 & 41740,76 & $-2,33$ \\
\hline 42264,10 & 40350,57 & $-4,74$ \\
\hline 40127,65 & 39693,13 & $-1,09$ \\
\hline
\end{tabular}

\begin{tabular}{|c|c|c|c|}
\hline $\begin{array}{c}\text { Equivalent } \\
\text { effort } 2009 \\
\text { [MPa] }\end{array}$ & $\begin{array}{c}\text { Equivalent } \\
\text { effort 2014 } \\
\text { [MPa] }\end{array}$ & $\begin{array}{c}\text { Location } \\
(\mathbf{x}, \mathbf{y}, \mathbf{z}) \\
{[\mathrm{mm}]}\end{array}$ & $\begin{array}{c}\text { Difference } \\
\%\end{array}$ \\
\hline 0,197 & 0,165 & $\begin{array}{c}-1.9 \\
-145,19 \\
-1232.71\end{array}$ & 16,2 \\
\hline $6,99 \mathrm{e}-05$ & $5,98 \mathrm{e}-05$ & $\begin{array}{c}-1.8, \\
-84.48, \\
-1247.70 \\
\end{array}$ & 14,44 \\
\hline $3,05 \mathrm{e}-04$ & $6,92 \mathrm{e}-04$ & $\begin{array}{c}-46.47, \\
-121.39 \\
-1220.77 \\
\end{array}$ & 126,88 \\
\hline $1,76 \mathrm{e}-03$ & $1,24 \mathrm{e}-03$ & $\begin{array}{c}35.46, \\
-123.72, \\
-1217.12 \\
\end{array}$ & 29,55 \\
\hline $3,06 \mathrm{e}-02$ & $2,58 \mathrm{e}-02$ & $\begin{array}{c}-25.21, \\
-133.30 \\
-1219.76 \\
\end{array}$ & 15,69 \\
\hline $2,07 \mathrm{e}-02$ & $2,69 \mathrm{e}-02$ & $\begin{array}{c}16.63, \\
-129.43, \\
-1221.05 \\
\end{array}$ & 29,95 \\
\hline
\end{tabular}

Table II. Equivalent effort of von Mises at the test points

To verify changes in geometry that imply the presence of metastases, the stress and strain fields were analyzed. Different test points were selected in the body, spinous and transverse process, in 
areas of high and low effort, (Figures 3 and 4) to assess whether stress concentrators were generated that could be caused by errors in the segmentation process or by degradation bone due to metastasis. It should be considered, however, the decrease in bone density due to the natural passage of time, this loss of bone mass is between $0.3 \%$ and $0.4 \%$ per year, after 35 years of age [23]. Considering this, an area was found where the density could decrease dramatically, as shown in Table 2. In the second point, analyzed in the spinous process, a variation in the stress field of $126 \%$ was calculated, which is associated with high loss of mass or alteration of bone mineral density. Table 2 also shows percentage changes between 15 and $30 \%$, associated with the annual loss of bone mass within the period analyzed.

Figures 3 and 4 show the changes in the distribution of deformation between the two vertebrae. Although

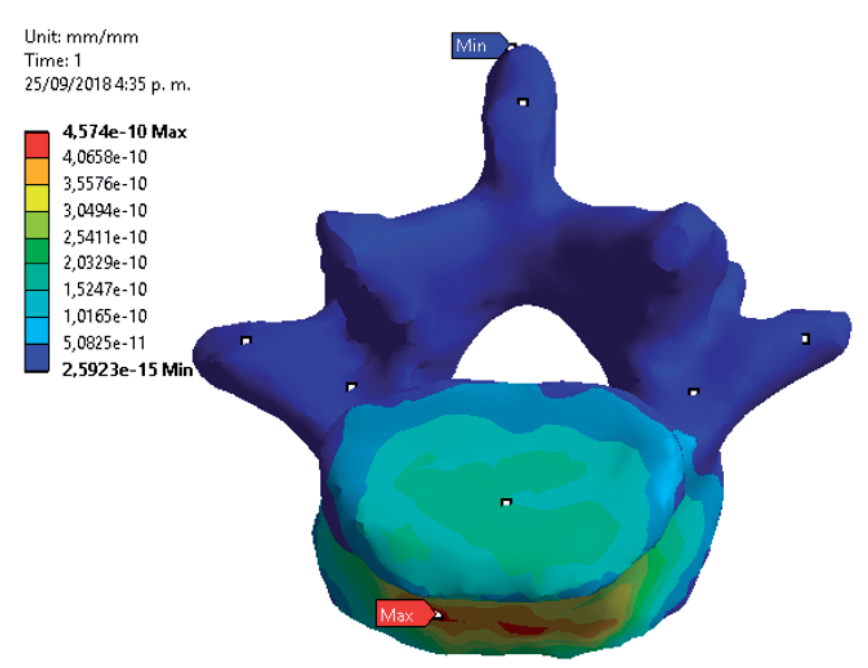

Figure 3. Vertebra deformation field of 2009

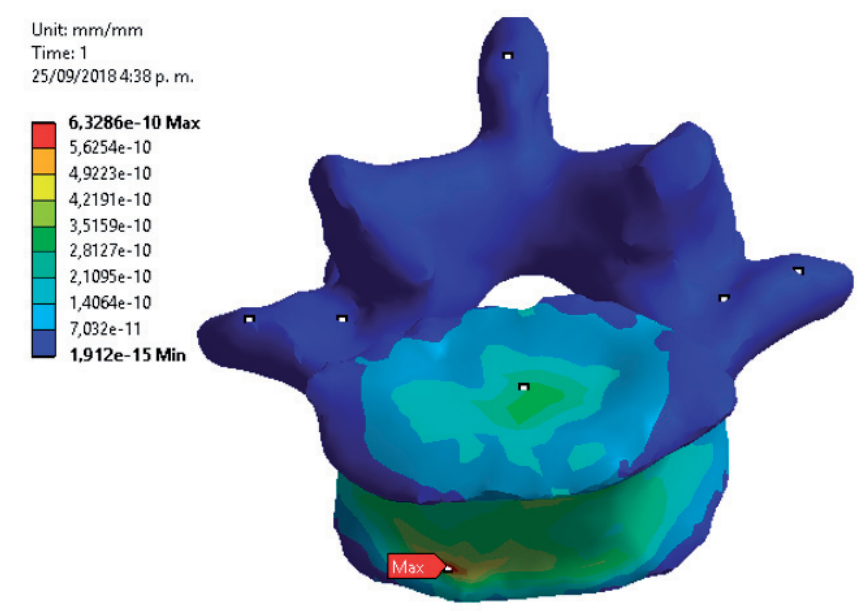

Figure 4. Vertebra deformation field of 2014 one of the points evaluated shows a great difference in the distribution of the efforts in one of the points, in the others this difference is not negligible, this can suppose an appearance of metastases over the entire vertebra [24].

To verify whether a metastasis lesion has appeared, the properties of the initial models were evaluated. The bone mineral density of the different slices of the critical points was measured. In the spinous process, the back of the vertebra, a $25 \%$ decrease in density was found and in general, over the entire vertebra mass losses were found, this type of metastasis is typical in $61 \%$ of patients with prostate cancer.

\section{Conclusions}

A methodology was evaluated to evaluate the presence of metastases in the vertebrae of patients suffering from prostate cancer. It was found that it is possible to study the mechanical response of the vertebrae models affected by cancer through $3 \mathrm{D}$ analysis and the finite element method and detect changes in bone composition to prevent validating lesions. The images from the TAC are used to create reliable models for this type of analysis, following a segmentation process that allows the material properties to be associated. A model with nonhomogeneous properties was implemented, where each element of the mesh had a density, elastic modulus and Poisson coefficient defined from the diagnostic image. Static analysis was performed with boundary conditions associated with typical loads to assess the mechanical response of bone tissue. The results showed that the vertebra suffered degradation in its mechanical properties in different parts of its domain, this case of degradation is typical when suffering from prostate cancer, and agrees with the clinical analysis. Future work includes the automation of the segmentation process and diagnosis of failure scenarios.

\section{Acknowledgments}

The authors appreciate the support received by the FM-2018-1 project, VIE Call, Universidad Industrial de Santander and the Ministry of Economy, Industry and Competitiveness of Spain (DPI2017-89816-R). 


\section{References}

[1] J. P. Karr, "Prostate Cancer in the United States and Japan", Prostate Cancer and Bone Metastasis. Advances in Experimental Medicine and Biology, Eds. Boston, MA: Springer, vol. 324, pp. 17-28, 1992.

[2] F. E. Lecouvet et al., "Magnetic resonance imaging of the axial skeleton for detecting bone metastases in patients with high-risk prostate cancer: Diagnostic and cost-effectiveness and comparison with current detection strategies", Journal of Clinical Oncology, vol. 25, no. 22, pp. 3281-3287, 2007. doi:10.1200/ JCO.2006.09.2940.

[3] G. R. Mundy, "Metastasis to bone: Causes, consequences and therapeutic opportunities", Nature Reviews Cancer, vol. 2, no. 8, pp. 584593, 2002. doi:10.1038/nrc867.

[4] Instituto Nacional de Cancerología - Colombia, "Cáncer en cifras", 2018. http://www.cancer. gov.co/ cancer_en_cifras, 2018/02/16

[5] M. Eleraky, I. Papanastassiou and F. D. Vrionis, "Management of metastatic spine disease", Current Opinion in Supportive and Palliative Care, vol. 4, no. 3, pp. 182-188, 2010. doi:10.1097/ SPC.0b013e32833d2fdd.

[6] D. Vanel, J. Bittoun and A. Tardivon, "MRI of bone metastases", European Radiology, vol. 8, no. 8, pp. 1345-1351, 1998. doi:10.1007/ s003300050549.

[7] H. K. Genant, K. Engelke and S. Prevrhal, "Advanced CT bone imaging in osteoporosis", Rheumatology, vol. 47, no. 4, 2008. doi:10.1093/rheumatology/ken180.

[8] R. Castilla, L. Forero and O. A. GonzálezEstrada, "Comparative study of the influence of dental implant design on the stress and strain distribution using the finite element method", Journal of Physics: Conference Series, vol. 1159, pp. 012016, 2018. doi:10.1088/1742-6596/1159/1/012016.
[9] M. Vera et al., "Segmentation of brain tumors using a semi-automatic computational strategy", Journal of Physics: Conference Series, vol. 1160, pp. $012002, \quad 2019$. doi:10.1088/1742-6596/1160/1/012002.

[10] E. Nadal-Soriano, M. J. Rupérez, S. MartínezSanchis, C. Monserrat-Aranda, M. Tur and F. J. Fuenmayor, "Evaluación basada en el método del gradiente de las propiedades elásticas de tejidos humanos in vivo", Revista UIS Ingenierías, vol. 16, no. 1, pp. 15-22, 2017. doi:10.18273/revuin.v16n1- 2017002.

[11] O. A. González-Estrada, S. Natarajan, J. J. Ródenas, H. Nguyen-Xuan and S. Bordas, "Efficient recovery-based error estimation for the smoothed finite element method for smooth and singular linear elasticity", Computational Mechanics, vol. 52, no. 1, pp. 37-52, 2013. doi:10.1007/s00466-012-0795-6.

[12] M. W. Layton, S. A. Goldstein, R. W. Goulet, L. A. Feldkamp, D. J. Kubinski and G. G. Bole, "Examination of subchondral bone architecture in experimental osteoarthritis by microscopic computed axial tomography", Arthritis \& Rheumatology, vol. 31, no. 11, pp. 1400-1405, 1988. doi:10.1002/ art.1780311109.

[13] E. Avrahami, R. Tadmor, O. Dally and H. Hadar, "Early MR Demonstration of Spinal Metastases in Patients with Normal Radiographs and CT and Radionuclide Bone Scans", Journal of Computer Assisted Tomography, vol. 13, no. 4, pp. 598-602, 1989. doi:10.1097/00004728-198907000-00008.

[14] S. Schievano et al., "Percutaneous Pulmonary Valve Implantation Based on Rapid Prototyping of Right Ventricular Outflow Tract and Pulmonary Trunk from MR Data", Radiology, vol. 242, no. 2, pp. 490-497, 2007. doi:10.1148/radiol.2422051994.

[15] F. Valencia-Aguirre, C. Mejía-Echeverria and V. Erazo-Arteaga, "Desarrollo de una prótesis de rodilla para amputaciones transfemorales usando herramientas computacionales", 
Revista UIS Ingenierías, vol. 16, no. 2, pp. 23-34, 2017. doi:https://doi.org/10.18273/ revuin.v16n2-2017002.

[16] W. C. C. Lee, M. Zhang, X. Jia and J. T. M. Cheung, "Finite element modeling of the contact interface between trans-tibial residual limb and prosthetic socket", Medical Engineering \& Physics, vol. 26, no. 8, pp. 655-662, 2004. doi:10.1016/j. medengphy.2004.04.010.

[17] S. A. Ardila-Parra, O. A. González-Estrada and J. E. Quiroga Mendez, "Damage Assessment of Spinal Bones due to Prostate Cancer", Key Engineering Materials, vol. 774, pp. 149154, 2018. doi:10.4028/www.scientific.net/ KEM.774.149.

[18] A. M. Pham, A. A. Rafii, M. C. Metzger, A. Jamali and E. B. Strong, "Computer modeling and intraoperative navigation in maxillofacial surgery", Otolaryngoly - Head Neck Surg, vol. 137, no. 4, pp. 624-631, 2007. doi:10.1016/j. otohns.2007.06.719.

[19] J. Y. Rho, M. C. Hobatho and R. B. Ashman, "Relations of mechanical properties to density and CT numbers in human bone", Medical Engineering \& Physics, vol. 17, no. 5, pp. 347-355, 1995. doi:10.1016/1350-4533(95)97314-F.

[20] J. H. Keyak, J. M. Meagher, H. B. Skinner and C. D. Mote, "Automated three-dimensional finite element modelling of bone: a new method", Journal of Biomedical Engineering, vol. 12, no. 5, pp. 389-397, 1990. doi:10.1016/0141-5425(90)90022-F.

[21] E. Schileo, F. Taddei, A. Malandrino, L. Cristofolini and M. Viceconti, "Subject-specific finite element models can accurately predict strain levels in long bones", Journal of Biomechanics, vol. 40, no. 13, pp. 2982-2989, 2007. doi:10.1016/j. jbiomech.2007.02.010.

[22] A. Nachemson, "The Load on Lumbar Disks in Different Positions of the Body", Clinical Orthopaedics andRelatedResearch, vol. 45, no.
1, pp. 107-122, 1966. doi:10.1097/00003086$196600450-00014$.

[23] J. D. Tobin, K. M. Fox, M. L. Cejku, T. A. Roy, R. S. Epstein and C. C. Plato, "Bone density changes in normal men: a 4-19 year longitudinal study", Journal of Bone and Mineral Research, vol. 8, no. 1, pp. S142, 1993.

[24] T. Suzuki, T. Shimizu, K. Kurokawa, H. Jimbo, J. Sato and H. Yamanaka, "Pattern of prostate cancer metastasis to the vertebral column", Prostate, vol. 25, no. 3, pp. 141-146, 1994. 